\begin{tabular}{l|l|l|l} 
Case Reports $h$ & Case Rep Dermatol 2009;1:82-86 & Published online: November 11, 2009 & $\begin{array}{l}\odot 2009 \text { S. Karger AG, Basel } \\
\text { ISSN 1662-6567 } \\
\text { www.karger.com/cde }\end{array}$ \\
\hline Dol: $10.1159 / 000251395$ & & & \\
\hline
\end{tabular}

\title{
Cherry Angiomas on the Scalp
}

\author{
Jae-Hong Kim Hwa-young Park Sung Ku Ahn \\ Department of Dermatology, Yonsei University Wonju College of Medicine, \\ Wonju, Korea
}

\section{Key Words}

Cherry angioma $\cdot$ Scalp

\begin{abstract}
Cherry angiomas are a common cutaneous vascular proliferation which manifests as single or multiple spots and occurs predominantly on the upper trunk and arms. They typically appear as round-to-oval, bright, red, dome-shaped papules and pinpoint macules measuring up to several millimeters in diameter. The histopathologic findings of a cherry angioma are consistent with a true capillary hemangioma, which is formed by numerous, newly developed capillaries with narrow lumens and prominent endothelial cells arranged in a lobular fashion in the papillary dermis. Herein, we report a case of multiple cherry angiomas on the scalp, an uncommon location for cherry angiomas.
\end{abstract}

\section{Introduction}

Cherry angiomas are the most common type of acquired vascular proliferation of the skin [1]. They are also known as cherry hemangiomas, senile angiomas, or Campbell de Morgan spots.

The etiology of cherry angiomas is not well-known. However, since cherry angiomas tend to increase in number as the patient's age increases, the aging process may play a role in the pathogenesis of cherry angiomas. Cherry angiomas have also been reported to be associated with pregnancy [2], climate [3], and exposure to chemicals [4-6]. Generally, cherry angiomas appear as 1 - to $5-\mathrm{mm}$, dome-shaped, bright, red papules located mainly on the trunk or upper extremities. However, they are rarely seen at other anatomic locations such as the face, hands and feet. We report a case of multiple cherry angiomas on the scalp, which is an unusual site for this type of lesion.

\section{Case Report}

A 41-year-old man presented with a 1-month history of multiple, bright, red papules on the scalp (fig. 1). He complained of progressive extension of these lesions and mild pruritus at the affected areas. He had no family history of similar lesions and an unremarkable medical history. Physical examination 


\begin{tabular}{|c|c|c|c|}
\hline $\begin{array}{l}\text { Case Reports in } \\
\text { Denil: id acil }\end{array}$ & $\begin{array}{l}\text { Case Rep Dermatol 2009;1:82-86 } \\
\text { D0I: } \underline{10.1159 / 000251395}\end{array}$ & Published online: November 11, 2009 & $\begin{array}{l}\text { (c) } 2009 \text { S. Karger AG, Basel } \\
\text { ISSN } 1662-6567 \\
\text { www.karger.com/cde }\end{array}$ \\
\hline
\end{tabular}

revealed 1- to 3-mm, multiple, bright, red papules throughout the scalp. A complete blood cell count and blood chemistry profile were within normal limits.

A skin biopsy specimen was taken from one of the papules on the scalp and stained with hematoxylin and eosin. Histopathological examination revealed capillaries composed of neovascularized vessels with thin lumens and lobular-patterned endothelium in the papillary dermis. Distended vessels formed loops and tortuous vessel channels with adjacent vessels (fig. 2).

Based on the clinical and histopathologic findings, he was diagnosed with cherry angiomas on the scalp. The patient was treated with cryotherapy and $\mathrm{CO}_{2}$ laser therapy every 2 weeks. After 2 months of treatment, his skin lesions and pruritus had nearly completely resolved.

\section{Discussion}

Cherry angiomas are the most common form of acquired vascular proliferation of the skin and were first described in 1872 by Campbell de Morgan [1]. The actual prevalence of cherry angiomas is not well-known, but one study reported that cherry angiomas were observed in $5 \%$ of adolescents and $75 \%$ of adults over 75 years of age [1]. Generally, cherry angiomas develop after the third decade, and the number of lesions increases with age. The etiology of cherry angiomas remains unknown. However, several factors are considered as inducing factors. One study has reported that cherry angiomas tend to be larger in diabetic patients [7], and another study reported that cherry angiomas have an increased expansion rate in tropical climates [3]. Cherry angiomas are also known to be related to chemical exposures [4-6]. Furthermore, cherry angiomas have been associated with liver transplants [8], graft-versus-host disease [9], and patients who are immunocompromised secondary to cyclosporine treatment [10]. In this case, the patient had no history of medical illness or exposure to chemicals. It is assumed that his lesions developed incidentally or as a result of an aging process.

Clinically, early lesions appear as flat, red macules that look like petechiae. As the lesions develop, they become 1- to 5-mm red papules. The lesions are usually asymptomatic, but may bleed with trauma. Cherry angiomas most commonly occur on the trunk or proximal extremities. However, they are rarely seen on other body parts such as face, hands and feet [11]. In fact, cherry angiomas on the scalp are rarely reported. For example, Keller reported that of hundreds of cases of cherry angiomas, only 2 cases were located on the scalp [12]. On the other hand, Pereira reported that a high frequency of cherry angiomas occurred on the scalp [13]. In Pereira's report, about $72 \%$ of patients had cherry angiomas on the scalp. There is a possibility that the actual incidence of cherry angiomas on the scalp may be much higher than what is currently reported.

Understandably, many people are not aware of cherry angiomas on the scalp, as they are usually asymptomatic and concealed under hair. Therefore, dermatologists should be aware that cherry angiomas can present as multiple macules or papules on the scalp. The clinical differential diagnosis for a scalp lesion that appears similar to a cherry angioma includes angiokeratoma, venous lake, pyogenic granuloma, and metastatic carcinoma. These diagnoses can be distinguished histologically.

Histological examination of cherry angiomas shows true capillary hemangiomas, formed by numerous, newly formed capillaries with narrow lumens and prominent endothelial cells arranged in a lobular pattern in the papillary dermis. In addition, collagen fibers between vessels appear to be homogeneous and show edematous changes.

While cherry angiomas are generally asymptomatic, some patients may want to remove these lesions for cosmetic reasons or for prevention of bleeding of these lesions following trauma. Management of cherry angiomas includes various modalities such as 


\begin{tabular}{|c|c|c|c|}
\hline $\begin{array}{l}\text { Case Reports in } \\
\text { Dematolagy }\end{array}$ & $\begin{array}{l}\text { Case Rep Dermatol 2009;1:82-86 } \\
\text { Dol: } \underline{10.1159 / 000251395}\end{array}$ & Published online: November 11, 2009 & \begin{tabular}{|l} 
| 12009 S. Karger AG, Basel \\
ISSN 1662-6567 \\
www.karger.com/cde
\end{tabular} \\
\hline
\end{tabular}

curettage, laser, and electrosurgery [14-15]. In our patient, treatment was performed with $\mathrm{CO}_{2}$ laser therapy and cryotherapy every 2 weeks. After 2 months of treatment, the patient's scalp lesions and pruritus had almost completely resolved.

In summary, we report an unusual case of cherry angiomas presenting as multiple, bright, red papules on the scalp, an uncommon location for these skin lesions.

Fig. 1. Picture of 1- to 3-mm, multiple, bright, red papules located on the scalp.

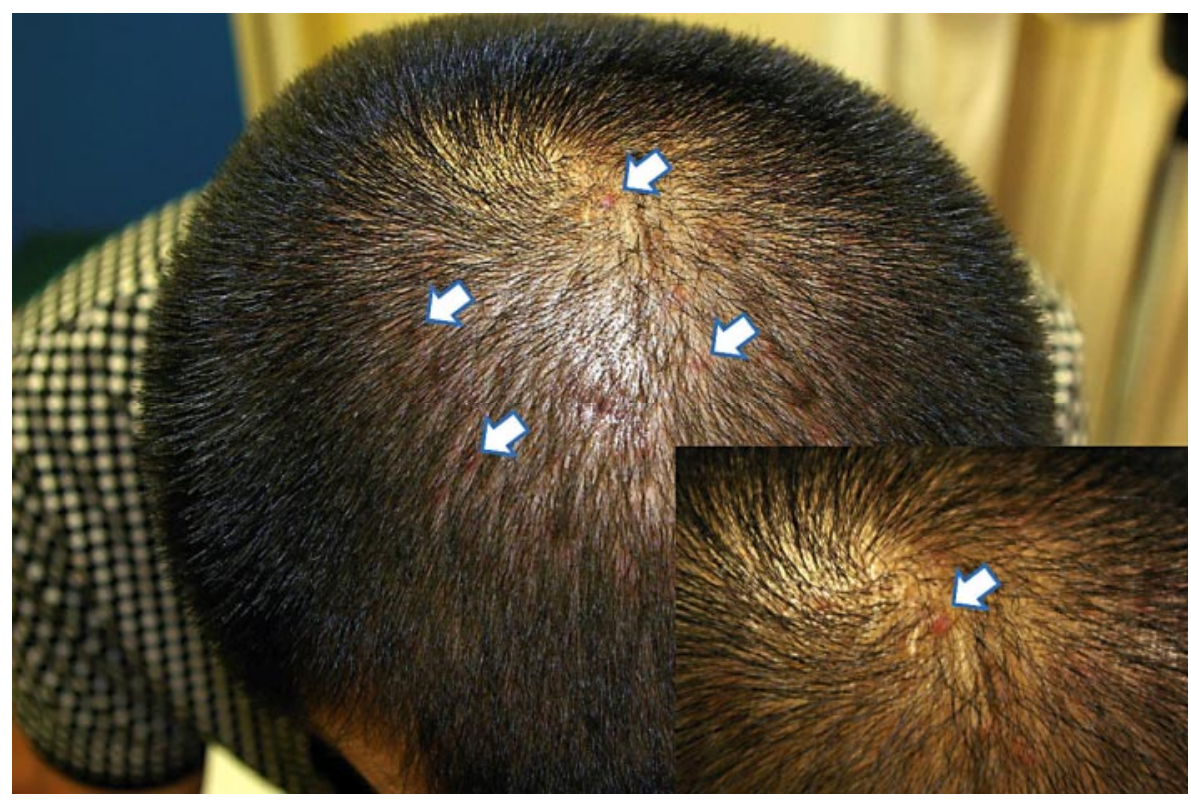




\begin{tabular}{|c|c|c|c|}
\hline $\begin{array}{l}\text { Case Reports in } \\
\text { Denmtiology }\end{array}$ & $\begin{array}{l}\text { Case Rep Dermatol 2009;1:82-86 } \\
\text { DOI: } \underline{10.1159 / 000251395}\end{array}$ & Published online: November 11, 2009 & $\begin{array}{l}\text { @ } 2009 \text { S. Karger AG, Basel } \\
\text { ISSN } 1662-6567 \\
\text { www.karger.com/cde }\end{array}$ \\
\hline
\end{tabular}

Fig. 2. Histopathologic findings show a thinned epidermis and numerous, newly formed capillaries with narrow lumens and prominent endothelial cells arranged in a lobular pattern in the papillary dermis (HE, $\times 40$, inset: $\times 200)$.

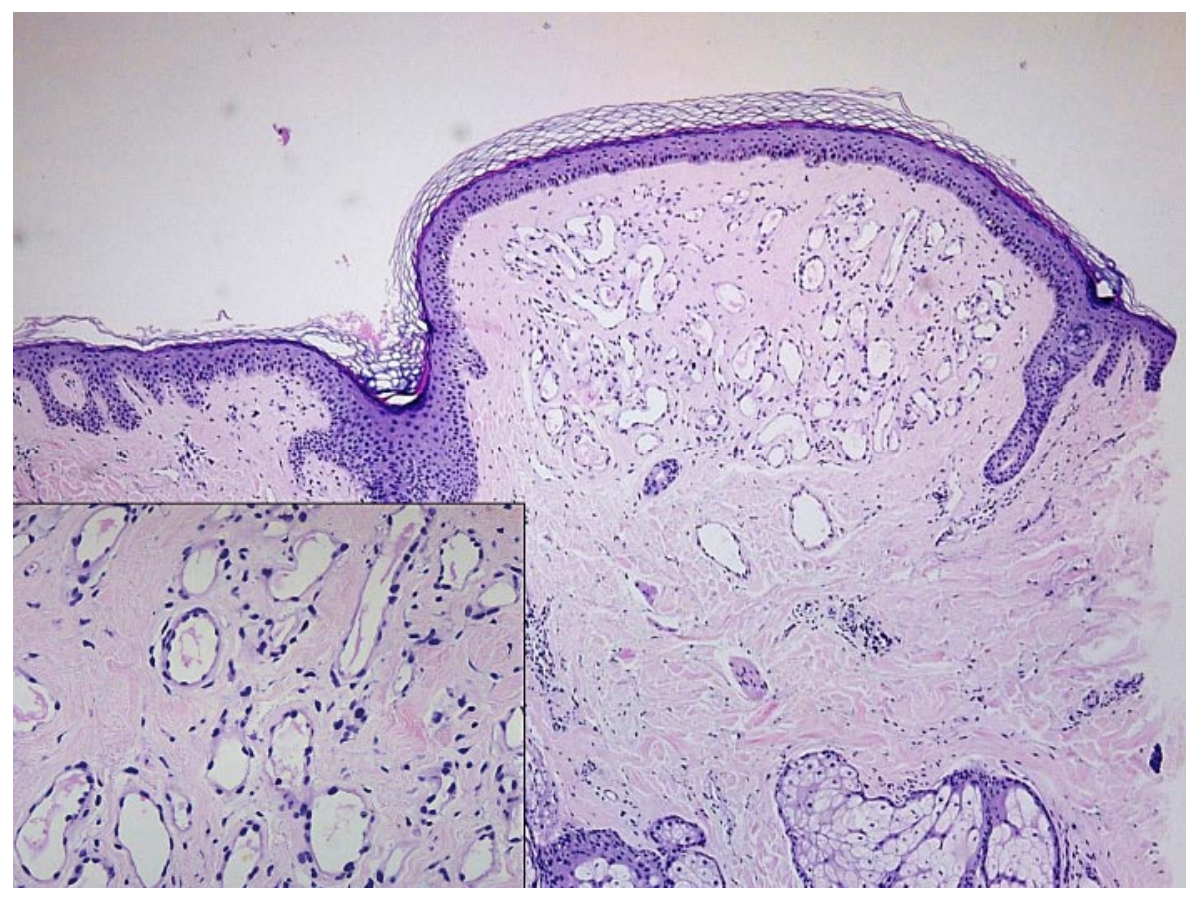




\section{References}

1 Murison AR, Sutherland JW, Williamson AM: De Morgan spots. Br Med J 1947;1:634-636.

-2 Barter RH, Letterman GS, Schurter M: Hemangiomas in pregnancy. Am J Obstet Gynecol 1963;87:625-635.

3 Jaimovich L: Por qué se multiplicfal los 'pontos rubi' con la edad? Act Terap Dermatol 1999;22:233-240.

$\checkmark 4$ Cohen AD, Cagnano E, Vardy DA: Cherry angiomas associated with exposure to bromides. Dermatology 2001;202:52-53.

5 Raymond LW, Williford LS, Burke WA: Eruptive cherry angiomas and irritant symptoms after one acute exposure to the glycol ether solvent 2-butoxyethanol. J Occup Environ Med 1998;40:1059-1064.

6 Firooz A, Komeili A, Dowlati Y: Eruptive melanocytic and cherry angiomas secondary to exposure to sulfur mustard gas. J Am Acad Dermatol 1999;40:646647.

7 Shah K, Shah AC, Shah PC: Campbell de Morgan's spots in diabetes mellitus. Br J Dermatol 1966;78:493-495.

$>8$ Chu P, Le Bolt PE: An eruptive vascular proliferation resembling acquired tufted angioma in the recipient of a liver transplant. J Am Acad Dermatol 1992;26:322325.

-9 Garnis S, Billick RC, Srolovitz H: Eruptive vascular tumors associated with chronic graft-versus-host disease. J Am Acad Dermatol 1984;10:918-921.

10 De Felipe I, Redondo P: Eruptive angiomas after treatment with cyclosporine in a patient with psoriasis. Arch Dermatol 1998;134:1487-1488.

11 Odom RB, James WD, Berger TG: Andrews' Disease of the Skin. 9th ed. Philadelphia, PA, WB Saunders, 2000, pp 733-799.

12 Keller VR: Zur Klinik und Histologie der senilen Angiome. Dermatologica 1957;114:345-359.

13 Pereira JM: Cherry hemangioma on the scalp. An Bras Dermatol 2004;79:83-89.

14 Aversa AJ, Miller OF 3rd: Cryo-curettage of cherry angiomas. J Dermatol Surg Oncol 1983;9:930-931.

15 Aghassi D, Anderson RR, Gonzalez S: Time-sequence histologic imaging of lasertreated cherry angiomas with in vivo confocal microscopy. J Am Acad Dermatol 2000;43:37-41. 